\title{
Regulation of Succinate Dehydrogenase in Escherichia coli
}

\author{
By J. RUÍZ-HERRERA AND L. G. GARCIA \\ Departamento de Microbiologia, Escuela Nacional de Ciencias Biologicas, \\ Instituto Politécnico Nacional, Mexico I7, D. F., Mexico
}

(Accepted for publication Io March 1972)

\begin{abstract}
SUMMARY
Washed suspensions of Escherichia coli oxidized succinate when previously grown on succinate but not on glucose. A slower rate of oxidation occurred with bacteria grown with peptone as carbon source. These differences were due to alterations in the level of succinate dehydrogenase activity. Glucose repressed the biosynthesis of the enzyme, whereas succinate acted as specific inducer and did not increase the activity of fumarate hydratase, malate dehydrogenase or NADH dehydrogenase. Aerobic growth also increased the levels of membrane-bound succinate dehydrogenase. Induction of succinate dehydrogenase by added succinate followed the expected kinetics. Addition of glucose caused a decline in the rate of biosynthesis of succinate dehydrogenase. Succinate dehydrogenase appears to play an important respiratory role since amytal (an NADH-oxidase inhibitor) inhibited growth only slightly when succinate was used as carbon source as compared to the strong inhibition of growth when glucose was used as carbon source.
\end{abstract}

\section{INTRODUCTION}

Succinate dehydrogenase is the only membrane-bound enzyme of the tricarboxylic acid cycle in Escherichia coli (Marr, 1960) and, therefore, it may participate in respiration besides functioning in the tricarboxylic acid cycle. Changes in the environment may consequently affect both respiratory activity and the functioning of the tricarboxylic acid cycle. Influence of growth conditions on the biosynthesis and activity of membrane-bound dehydrogenases and cytochromes of bacteria is well documented (Gray, Wimpenny \& Mossman, 1966; Cavari, Avi-Dor \& Gressowicz, 1968; Ruíz-Herrera \& De Moss, 1969). Preliminary studies (Ruíz-Herrera, I968) have suggested that the carbon growth substrate was important in governing the synthesis of succinate dehydrogenase in $E$. coli. This study presents further data on the mechanisms which control the biosynthesis of succinate dehydrogenase in this bacterium.

\section{METHODS}

Organism and growth conditions. Escherichia coli $\mathrm{HfrH}$, obtained from J. A. de Moss, University of California, San Diego, U.S.A., was maintained on nutrient agar (Difco) and grown on the medium described by Sypherd \& Strauss (1963) with $5 \mu \mathrm{g}$ of thiamine/ml and either I $\%$ glucose or $0.5 \%$ succinate. This medium is referred to as 'synthetic medium'; for 'complex medium', nutrient broth (Difco) at $0.4 \%$ was added. Bacteria were grown at $37^{\circ} \mathrm{C}$ for 4 to $5 \mathrm{~h}$, the medium being sparged with about 2 volumes of sterile air/volume of culture/min. For anaerobic conditions, cultures were sparged with a mixture of $95 \% \mathrm{~N}_{2}+5 \%$ $\mathrm{CO}_{2}$. Bacterial density was measured by means of a Klett photocolorimeter using a green filter and the protein content was calculated from the turbidity with an appropriate calibration curve. 
Preparation of bacteria-free extracts and bacterial envelopes. Bacteria were centrifuged,

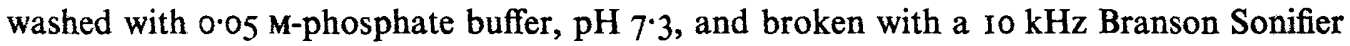
(Heat Systems Ultrasonics, Plainview, New York, U.S.A.) for three successive periods of $15 \mathrm{~s}$ each. The extract was centrifuged at $400 \mathrm{~g}$ for $15 \mathrm{~min}$ and the supernatant used as crude extract. Bacterial envelopes were isolated by resuspending the bacteria in $0.5 \mathrm{ml}$ of $0.05 \mathrm{M}$-tris-HCl buffer, $\mathrm{pH} \mathrm{8.3,} \mathrm{containing} 20 \%$ sucrose and $2 \mathrm{mg}$ lysozyme (Sigma Chemical Co. Inc., St Louis, Missouri, U.S.A.)/ml and frozen in an acetone-solid $\mathrm{CO}_{2}$ mixture. After thawing at $37^{\circ} \mathrm{C}$, the treatment was repeated four times. Five $\mathrm{ml}$ of $0.05 \mathrm{M}$-phosphate buffer containing $10 \mu \mathrm{g}$ DNase (Sigma Chemical Co.)/ml were added and rapidly mixed until the viscosity decreased. The crude extract was centrifuged at $50000 \mathrm{~g}$ for $\mathrm{Io} \mathrm{min}$, the supernatant removed and the residue resuspended in $\mathrm{I} \mathrm{ml}$ of phosphate buffer and centrifuged at $500 \mathrm{~g}$ in a linear sucrose gradient ( 50 to $20 \%$ ) for $20 \mathrm{~min}$. Bacterial envelopes appeared as an opalescent band within the gradient.

Determination of respiratory activity. Oxygen uptake was measured with a Clark oxygen electrode(Yellow Spring Instrument Co. Inc., Ohio, U.S.A.), attached to a Perspex cylindrical chamber with a capacity of $3.2 \mathrm{ml}$.

Measurement of succinate uptake. Samples $(5 \mathrm{ml})$ of bacterial suspensions in $0.05 \mathrm{M}$ phosphate buffer, $\mathrm{pH} 7 \cdot 3$, at a turbidity of 360 Klett units $(=\mathrm{I} \cdot 4 \mathrm{mg}$ dry wt bacteria/ml) were incubated with $0.2 \mathrm{ml} 0.05 \mathrm{M}-\left[\mathrm{I}, 4^{-14} \mathrm{C}_{2}\right]$ succinate (sp.act. $0.0 \mathrm{I} \mu \mathrm{Ci} / \mu \mathrm{mol}$ ) (Calbiochem Inc., La Jolla, California, U.S.A.). At intervals, I $\mathrm{ml} \mathrm{samples} \mathrm{were} \mathrm{removed} \mathrm{and} \mathrm{mixed} \mathrm{with}$ I $\mathrm{ml} \mathrm{O.I} \mathrm{M-KCN} \mathrm{(at} 0^{\circ} \mathrm{C}$ ) and filtered through membrane-filters $(0.47 \mu \mathrm{m}$ pore diameter, Millipore Corporation, Bedford, Massachusetts, U.S.A.). The bacteria were washed with $5 \mathrm{ml}$ of ice-cold $0.1 \mathrm{M}-\mathrm{KCN}$. Radioactivity of the cells was measured with a Geiger counter (Phillips, Model 4035) which had an absolute efficiency of $2.5 \%$ for ${ }^{14} \mathrm{C}$. No correction for self-absorption was made.

Enzymatic activities. Succinate dehydrogenase was measured by the method of Ells (I959). Rate of dichloro-indophenol reduction was measured with a Maroc V (Jobin et Ivon, Arcueil, France) spectrophotometer coupled to a Photo-Volt Model 43 recorder. Activity was expressed as $\Delta E_{600 \mathrm{~mm}} / \mathrm{min} / \mathrm{mg}$ of protein. Fumarate hydratase was measured by the method of Massey (1955), and activity expressed as $\Delta E_{300 \mathrm{~nm}} / \mathrm{min} / \mathrm{mg}$ of protein. Malate dehydrogenase was measured as described in the brochure Enzymes, Enzyme Reagents from Worthington Biochemical Corp., Freehold, New Jersey, U.S.A. Activity was expressed as $\Delta E_{340 \mathrm{~mm}} / \mathrm{min} / \mathrm{mg}$ protein. NADH dehydrogenase was measured as follows: $0.2 \mathrm{ml}$ of 0.0015 M-NADH was mixed with $2.7 \mathrm{ml}$ of $0.05 \mathrm{M}$-phosphate buffer, $\mathrm{pH} 7.3$, and $0.2 \mathrm{ml}$ of bacterial extract. Activity was measured as described for succinate dehydrogenase and expressed as $\Delta E_{340 \mathrm{~nm}} / \mathrm{min} / \mathrm{mg}$ protein.

Protein was measured by the method of Lowry, Rosebrough, Farr \& Randall (I95I).

\section{RESULTS}

Succinate was not as good a carbon source as glucose for the growth of Escherichia coli. When both substrates were added to a synthetic medium, diauxic growth occurred with glucose being used first. The effect of glucose was attributed to alterations in the respiratory activity as glucose-grown bacteria did not oxidize succinate (Table I). Differences in respiratory activity between glucose- and succinate-grown bacteria correlated with the activity of succinate dehydrogenase in extracts from the two types of bacteria (Table I). However, permeability to $\left[1,4-{ }^{14} \mathrm{C}_{2}\right]$ succinate was not greatly affected by the conditions of growth (Fig. I). 


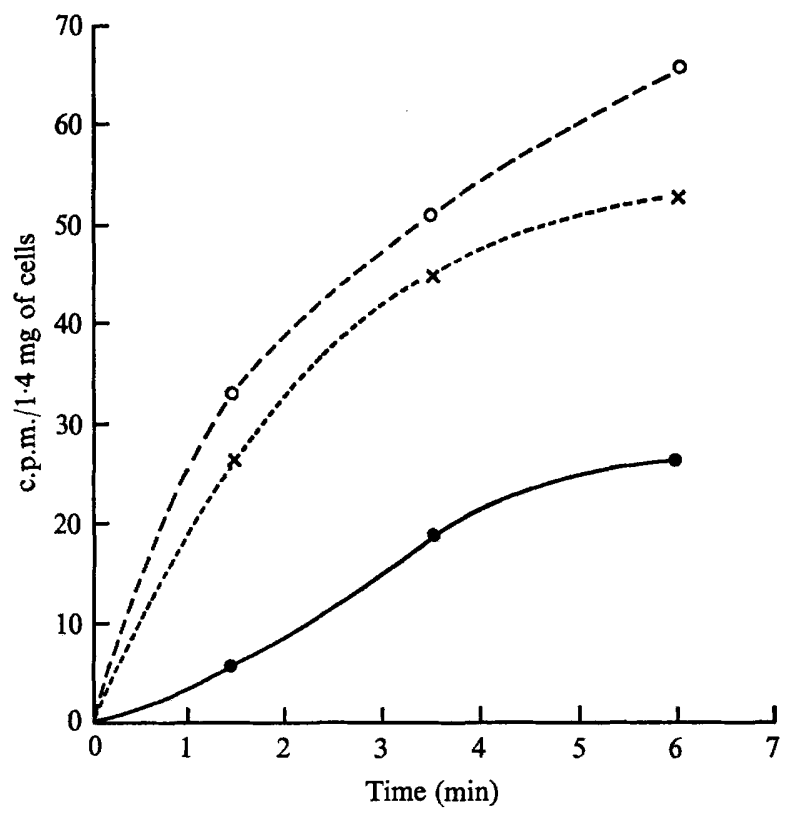

Fig. I. Uptake of $\left[1,4^{14} \mathrm{C}_{2}\right]$ succinate into Escherichia coli. Bacteria were grown for $4 \mathrm{~h}$ in complex medium alone or with succinate or glucose added. Uptake of $\left[1,4^{-14} C_{2}\right]$ succinate was followed as described in Methods. $\bigcirc$. Succinate-grown bacteria; $\bigcirc$, glucose-grown bacteria; $\times$, bacteria grown in complex medium alone.

Table I. Effect of carbon source on respiratory and succinate dehydrogenase activities

\begin{tabular}{|c|c|c|c|c|}
\hline \multirow[b]{2}{*}{ Medium } & \multirow[b]{2}{*}{$\begin{array}{l}\text { Additional } \\
\text { carbon source }\end{array}$} & \multicolumn{2}{|c|}{$\begin{array}{l}\text { Respiratory activity } \\
\text { Substrate }\end{array}$} & \multirow{2}{*}{$\begin{array}{c}\text { Specific activity } \\
\text { of succinate } \\
\text { dehydrogenase } \\
\left(\Delta E_{800} / \mathrm{min} / \mathrm{mg}\right. \\
\text { protein })\end{array}$} \\
\hline & & $\begin{array}{r}\text { Glucose } \\
\left(\mu 1 \mathbf{O}_{2}\right.\end{array}$ & $\begin{array}{l}\text { Succinate } \\
\text { protein) }\end{array}$ & \\
\hline Synthetic & $\begin{array}{l}\text { Glucose } \\
\text { Succinate }\end{array}$ & $\begin{array}{l}6 \cdot 9 \\
3 \cdot 6\end{array}$ & $\begin{array}{c}0 \\
4.9\end{array}$ & $\begin{array}{l}0.17 \\
1 \cdot 32\end{array}$ \\
\hline Complex & $\begin{array}{l}\text { None } \\
\text { Glucose } \\
\text { Succinate }\end{array}$ & E & $\begin{array}{c}2 \cdot I \\
0 \\
6 \cdot 3\end{array}$ & $\begin{array}{l}0.12 \\
0.04 \\
0.39\end{array}$ \\
\hline
\end{tabular}

Isolated bacterial envelopes readily oxidized succinate and $\mathrm{NADH}$, but not glucose. NADH oxidation by envelopes from glucose- and succinate-grown bacteria was about the same but succinate was oxidized more rapidly by envelopes from succinate-grown bacteria. These differences were related to the activity of the corresponding enzymes (see Table 2).

The effect of succinate as inducer of succinate dehydrogenase was specific since its addition to complex medium significantly increased the synthesis only of succinate dehydrogenase, whereas fumarate hydratase and malate dehydrogenase were not affected (Table 3). Glucose did not repress the latter two enzymes as much as it did succinate dehydrogenase (Table 3).

The absence of oxygen during growth also affected the respiratory activity and the levels of succinate dehydrogenase. Bacteria grew poorly with succinate as carbon source under anaerobic conditions and had $25 \%$ of the respiratory activity with succinate and only $8 \%$ 
Table 2. Enzymatic and respiratory activities in envelopes isolated from Escherichia coli grown aerobically in complex medium

\begin{tabular}{|c|c|c|c|c|}
\hline \multirow[b]{3}{*}{$\begin{array}{l}\text { Additional } \\
\text { carbon source }\end{array}$} & \multirow{2}{*}{\multicolumn{2}{|c|}{$\begin{array}{l}\text { Respiratory activity. } \\
\text { Substrate }\end{array}$}} & \multicolumn{2}{|c|}{ Specific activities of } \\
\hline & & & \multirow{2}{*}{$\begin{array}{c}\text { Succinate } \\
\text { dehydrogenase } \\
\left(\Delta E_{600} / \mathrm{min} / \mathrm{mg}\right. \\
\text { protein })\end{array}$} & \multirow{2}{*}{$\begin{array}{c}\text { NADH } \\
\text { dehydrogenase } \\
\left(\Delta E_{340} / \mathrm{min} / \mathrm{mg}\right. \\
\text { protein) }\end{array}$} \\
\hline & $\begin{array}{l}\text { Succinate } \\
\qquad\left(\mu 1 \mathrm{O}_{2} / \mathrm{n}\right.\end{array}$ & $\begin{array}{l}\text { NADH } \\
\text { otein) }\end{array}$ & & \\
\hline None & 一 & 一 & 0.89 & $3 \cdot 8$ \\
\hline Glucose & 0.59 & $5 \cdot 15$ & 0.44 & $5 \cdot 2$ \\
\hline Succinate & $6 \cdot 59$ & $4 \cdot 11$ & $4 \cdot 44$ & $3 \cdot 8$ \\
\hline
\end{tabular}

Table 3. Effect of culture condition on the synthesis of several enzymes from the tricarboxylic acid cycle from Escherichia coli grown aerobically in complex medium

\begin{tabular}{|c|c|c|c|}
\hline \multirow[b]{2}{*}{$\begin{array}{l}\text { Additional } \\
\text { carbon source }\end{array}$} & \multicolumn{3}{|c|}{ Enzyme activity } \\
\hline & $\begin{array}{c}\text { Succinate } \\
\text { dehydrogenase* }\end{array}$ & $\begin{array}{c}\text { Fumarate } \\
\text { hydratase } \dagger\end{array}$ & $\begin{array}{c}\text { Malate } \\
\text { dehydrogenase } \neq\end{array}$ \\
\hline None & 0.270 & 0.0054 & 0.350 \\
\hline Glucose & 0.022 & 0.0056 & $0.16 \mathrm{I}$ \\
\hline Succinate & 0.850 & 0.0077 & 0.360 \\
\hline & $\begin{array}{l}* \Delta E_{600} / \mathrm{mi} \\
\dagger \Delta E_{300} / \mathrm{mi} \\
+\Delta E_{340} / \mathrm{mi}\end{array}$ & $\begin{array}{l}\text { tein. } \\
\text { tein. } \\
\text { tein. }\end{array}$ & \\
\hline
\end{tabular}

of succinate dehydrogenase activity as compared with bacteria grown aerobically. The amount of succinate dehydrogenase present in glucose-grown cells was independent of the oxygen concentration.

Kinetics of succinate dehydrogenase induction were measured under conditions where succinate was not the limiting factor for growth (Fig. 2). After succinate was added to the growth medium, the induction of the enzyme followed the classical kinetics described by Jacob \& Monod (196I) for an inducible system. When chloramphenicol $(50 \mu \mathrm{g} / \mathrm{ml})$ was added simultaneously with succinate, no increase in activity of succinate dehydrogenase was obtained.

In a further experiment repression by glucose of the enzyme system in bacteria growing on succinate was followed (Fig. 3). Synthesis of succinate dehydrogenase stopped immediately after glucose was added to the medium and existing enzyme decayed rapidly indicating that either it has a rapid turnover rate or that glucose favours its degradation or inactivation.

When glucose was removed from succinate-containing medium, enzyme synthesis was immediately restored following similar kinetics to that shown in Fig. 2.

The role of succinate dehydrogenase in respiration of the bacterium was investigated by observing the effect of amytal on growth. Amytal inhibits NADH dehydrogenase of mitochondria (Chance \& Hollunger, 1963) and also NADH oxidase from Agrobacterium tumefaciens (Kurup, Vaidyanathan \& Ramasarma, 1966). With an envelope preparation from Escherichia coli 0.6 mM-amytal inhibited NADH oxidation by $40 \%$ but had no effect on succinate oxidation. If amytal inhibited NADH oxidation, but not succinate oxidation, addition of amytal to a medium with substrates which were oxidized via NAD would bring about 


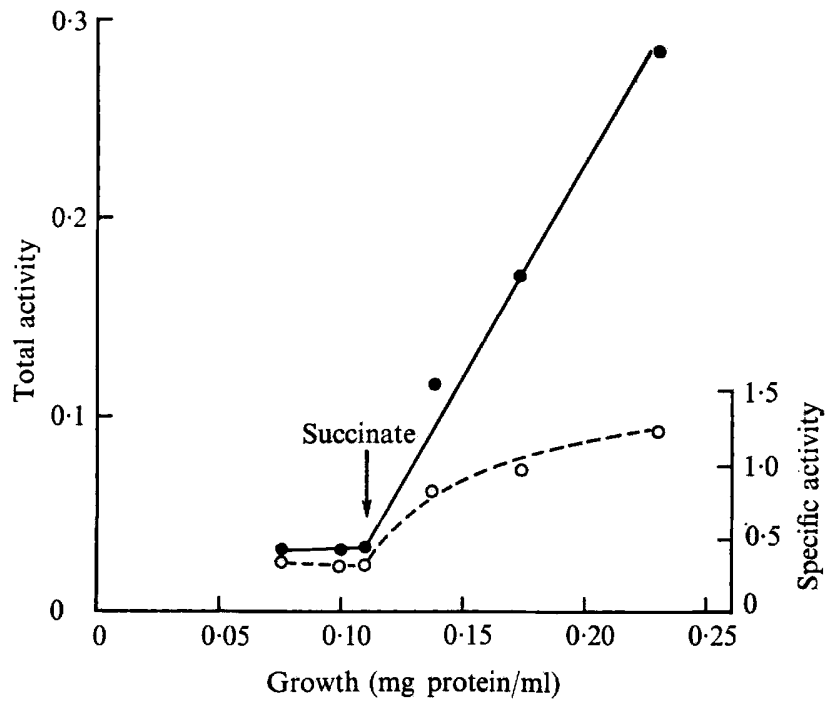

Fig. 2. Induction of succinate dehydrogenase in Escherichia coli. Escherichia coli was grown in aerated complex medium for $130 \mathrm{~min}$ and $0.5 \%$ succinate then added. Samples were removed, washed in buffer containing $50 \mu \mathrm{g}$ chloramphenicol $/ \mathrm{ml}$ and sonicated. Specific activity of succinate dehydrogenase, $O$, is expressed as $E_{600} / \mathrm{min} / \mathrm{mg}$ protein. Total activity, $O$, is for I ml culture medium.

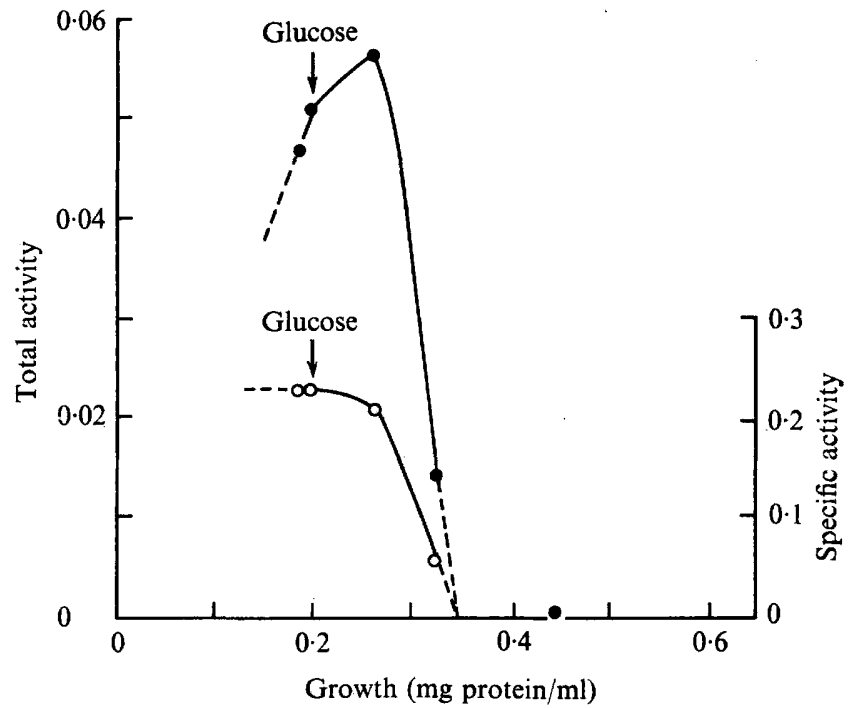

Fig. 3. Repression of succinate dehydrogenase by glucose in Escherichia coli. Bacteria were grown in complex medium for $3 \mathrm{~h}$ and $0.75 \%$ glucose was added. At intervals samples were removed and treated as described for Fig. 2. Specific activity, $\bigcirc$, and total activity, , are expressed as in Fig.2. 
a stronger inhibition than when it was added to a medium where the respiratory substrate was succinate. Thus 0.1 mM-amytal inhibited growth of $E$. coli in complex medium by $30 \%$ when glucose was present but only by $10 \%$ when succinate was added instead of glucose. When I mm-amytal was used, growth inhibition was $60 \%$ and $20 \%$ respectively.

\section{DISCUSSION}

The formation of succinate dehydrogenase in Escherichia coli is controlled by the environmental conditions. Its repression by glucose is another example of an enzyme subject to catabolite repression (Magasanik, I96I). Glucose had little effect on the synthesis of malate dehydrogenase and the permeability system for succinate. Glucose does repress the synthesis of succinate dehydrogenase in Haemophilus parainfluenzae (White, 1967) and Staphylococcus aureus (Collins \& Lascelles, 1962). With $E$. coli grown in complex medium, the formation of enzymes of the tricarboxylic acid cycle is also repressed by glucose (Gray et al. 1966). We found a more specific effect of glucose since fumarate hydratase was not repressed by the carbohydrate.

The induction of succinate dehydrogenase in Escherichia coli $\mathrm{HfrH}$ by succinate is similar to that reported by Cavari et al. (1968) who found that the activity of succinate dehydrogenase increased about sixfold when $E$. coli was grown in a succinate-containing medium as compared to the activity shown by bacteria grown in a medium containing fumarate or mannitol.

Our data on the levels of succinate dehydrogenase in aerobically and anaerobically grown cells agree with those reported by Gray et al. (1966), Hino \& Maeda (1966), and Cavari et al. (1968). Location within the membrane confers special characteristics to succinate dehydrogenase, as has been discussed by Cerletti, Gioveno, Testolin \& Binotti (1968); of special interest is that succinate dehydrogenase may have a respiratory role according to our results.

This work was carried out with the financial help from the C.O.F.A.A. of the Instituto Politécnico Nacional and a grant from the Research Corporation, Brown Hazen Fund.

\section{REFERENCES}

Cavari, B. Z., Avi-Dor, Y. \& Grossowicz, N. (1968). Induction by oxygen of respiration and phosphorylation of anaerobically grown Escherichia coli. Journal of Bacteriology 96, 75I-759.

Cerletti, P., Gioveno, S., Testolin, G. \& BinotTi, I. (1968). Membrane bound and soluble succinate dehydrogenase. In Membrane Models and the Formation of Biological Membranes, p. 166. Edited by L. Bolis \& A. B. Pethica. New York, U.S.A.: John Wiley \& Sons Inc.

Chance, B. \& Hollunger, G. (1963). Inhibition of electron and energy transfer in mitochondria. I. Effects of amytal, thiopental, rotenone, progesterone, and methylene glycol. Journal of Biological Chemistry 278, 418-43I.

Collins, F. M. \& LASCElles, J. (1962). The effect of growth conditions on oxidative and dehydrogenase activity in Staphylococcus aureus. Journal of General Microbiology 29, 53I-539.

Elus, A. H. (1959). A colorimetric method for the assay of soluble succinic dehydrogenase and pyridine nucleotide-linked dehydrogenases. Archives of Biochemistry and Biophysics 85, 56I-562.

Gray, C. T., WimpenNy, J. W. T. \& Mossman, M. R. (1966). Regulation of metabolism in facultative bacteria II. Effect of aerobiosis, anaerobiosis and nutrition on the formation of the Krebs cycle enzymes in Escherichia coli. Biochimica et biophysica acta 117, 33-4I.

HiNo, S. \& MAEDA, M. (1966). Effect of oxygen on the development of respiratory activity in Escherichia coli. Journal of General and Applied Microbiology 12, 247-265.

JACOB, F. \& MONOD, J. (196I). Genetic regulatory mechanisms in the synthesis of proteins. Journal of Molecular Biology 3, 318-356. 
Kurup, C. K., Vaidyanathan, C. \& Ramasarma, C. (1966). NADH oxidase system of Agrobacterium tumefaciens. Archives of Biochemistry and Biophysics Ir3, 548-553.

Lowry, O. H., Rosebrough, N. J., Farr, A. L. \& Randall, R. J. (I95I). Protein measurement with the Folin phenol reagent. Journal of Biological Chemistry r93, 265-275.

MagasaniK, B. (1961). Catabolite repression. Cold Spring Harbor Symposium on Quantitative Biology 26, 249-256.

MARR, G. A. (1960). Localization of enzymes in bacteria. In The Bacteria, vol. I, p. 443. Edited by I. C. Gunsalus \& R. Y. Stanier. New York: Academic Press.

Massey, V. (1955). Fumarase. In Methods in Enzymology, vol. I, p. 729. Edited by S. P. Colowick \& N. O. Kaplan. New York: Academic Press.

Ruíz-HerRera, J. (I968). Inducción de succínico deshidrogenasa en Escherichia coli y su posible significación en el concepto de transporte respiratorio en bacterias. Proceedings. VII National Congress of Microbiology, p. 152. México: Guadalajara.

Ruíz-HerRera, J. \& De Moss, J. A. (1969). Nitrate reductase complex of Escherichia coli K-I 2: Participation of specific formate dehydrogenase and cytochrome $b_{1}$ components in nitrate reduction. Journal of Bacteriology 99, 720-729.

SYPHERD, P. S. \& Strauss, N. (1963). Chloramphenicol promoted repression of $\beta$ galactosidase synthesis in Escherichia coli. Proceedings of the National Academy of Sciences of the United States of America 49, 400-407.

WHITE, D. C. (1967). Effect of glucose on the formation of the membrane bound electron transport system in Haemophilus parainfluenzae. Journal of Bacteriology 93, 567-573. 